\title{
Passion Music at the Turn of the XX and XXI Centuries, Part I: Sofia Gubaidulina and Wolfgang Rihm
}

The great conductor and scholar of the works of Bach, Helmuth Rilling, commissioned his colleague composers from different countries to write works on the Passion of Christ inspired by the four Gospels. This project known as Passion 2000 was realized on the $250^{\text {th }}$ anniversary of Bach's death. As part of this valuable initiative and tribute to the Bach, the Russian composer Sofia Gubaidulina, the German composer Wolfgang Rihm, the Chinese composerTan Dun, and the Argentinian composer Osvaldo Goliovo created four considerable works that completely differ stylistically and provide new perspectives on Passion settings. This article presents the following two European Passions from a historical perspective: the St. John Passion by Sofia Gubaidulina and the Deus Passus by Wolfgang Rihm. These composers' perspectives of the Passion genre expand the traditional framework of this genre as they present the events of the Passion within contemporary contexts and combine musical styles from different historical periods.

Key words: Passion, Wolfgang Rihm, Sofia Gubaidulina, contemporary sacred music, St. John Passion, Deus Passus.

One cannot remain indifferent to the topic of the Passion. Every year for centuries, cultures and traditions have recalled the revelation of the mystery of the cross, the sorrow of the Mother of God, and the sacrifice of Jesus Christ. This teaching arises from the moment that is the most important to Christians: the Death and Resurrection of 
Christ. The essence of Passion works is to remind man about his need to repent, do penance, and convert. In the history of music, compositions on Christ's Passion are some of Christian culture's oldest works. Regardless of whether these works were sung according to ascetic Gregorian melodies or, in later centuries, full of baroque ecstasy, the Gospel message was always the power behind their influence. The music of the Passion sequences was meant to support the Word, convey its message and emotions, and help the faithful to find the way to God. The richness of the oldest Polish Passion hymns is as remarkable as the Mystery about which they speak. Thanks to these hymns, one can encounter past biblical events, since these works transport listeners back in time so that they can witness the Lord's Passion.

The word "passion" comes from the Latin word "passio," which means suffering, illness, torment, as well as feelings and passions that are intensified. In the Christian religion, the word "passion" is used to refer to the Lord's Suffering and Death-to the last hours of Jesus Christ's life: from when Christ was in the Garden of Gethsemane on Holy Thursday until his death on the Cross on Golgotha on Good Friday.

The Passion first began to be intoned during the Middle Ages. As such, it was one of the first musical genres of that time, which then served to shape Christian consciousness for centuries to follow. As a musical genre, Passions grew out of choral practices; its Gregorian roots influenced the later sounds and structures of individual Passions, the starting points of which were the words of one of the four Gospels. As a very important musical form that took up the key theme of Christianity-namely, the Death and Resurrection of Jesus Christ, both historical and more current Passions deserve to be closely considered. Beginning in the $4^{\text {th }}$ century, the Gospel was intoned during the liturgy of Holy Week. In $900 \mathrm{AD}$, the monks of the monastery of St. Gallen used dialogue tropes in order to ennoble the celebrations of the most important religious holy days. In this way, dramatic liturgical dramas also known as church dramas or mysteries came to be. Visitatio Sepulchri, which is also known as Ludus Trium Personarum, is an example of such dramas. The Benedictines in Winchester kept the first record of these kinds of plays. Gradually, the so-called "Passion plays" occurred during Lent from Palm Sunday to Good Friday. Over time, the Passion plays became a popular means to share the Gospel message, and the practice spread to all of the important centers of Catholic worship. The choral Passion was originally sung by three priests each of who respectively played the role of: Christ, the narrator, 
and the crowd. Their parts varied in the range of their registers and tempo. For example, the role of Christ was often sung in the lowest range at a slower tempo in keys c-f minor (most often by the bass); the narrator, meaning the role of the Evangelist, was sung at a moderate tempo in keys f-c minor-(most often by the tenor); and the crowd was sung at a quick tempo in the high register of the keys c-f minor. In subsequent centuries, this initial diversity in the specific vocal roles influenced the internal division of form of the Passion plays as well as the character of future Passion works.

During the Renaissance, the Passions took the form of polyphonic arrangements. These include the outstanding works of Obrecht, Palestrina, and di Lasso. Later on in the history of music, Heinrich Schütz's composed three Passions in 1666 according to the Gospels of Matthew, Luke, and John, respectively. Christ dying on the cross Theology of Beauty has inspired painters, poets, and composers to depict unimaginably powerful emotions for centuries. Among these works of art, there is John Sebastian Bach's brilliant and masterfully composed Passions. In a sense, all of the Passions that were composed after Bach refer either consciously or subconsciously to his masterpieces.

Passions written in the $20^{\text {th }}$ century began a completely new chapter both in the history of music and the Passion genre itself. For example, the role of these Passions changed in the $20^{\text {th }}$ century; no longer were they intended as musical settings to be used in a church during Holy Week. Instead, they were prepared as concerts. In this way, the Passions' original purpose to aid the faithful in their prayer became secondary. Those who came to listen to the music, therefore, were not so much the faithful who lead a religious life, but those who wish to enjoy musical art. This, however, does not diminish the depth of the message that the Passions convey.

As the context of the music was transformed from church to concert music, composers felt freer to use novel forms of composition that differed from the traditional musical techniques of past composers. The new musical styles of $20^{\text {th }}$ century also resulted in new perspectives both in the Passion genre along with other genres of music wherein composers became open to experimenting by adding new content, including non-Gospel texts and scenic, dance, multimedia, and other experimental elements.

Helmuth Rilling's Passion 2000 project to commemorate the $250^{\text {th }}$ anniversary of Bach's death, and his request for Passion compositions resulted in four distinct and extraordinary works by composers from four different countries, cultures, and continents. These works provide 
new perspectives on the Passion genre. This article will discuss two works—-those of Sofia Gubaidulina and Wolfgang Rihm—below.

\section{Sofia Gubaidulina - St. John Passion}

Gubaidulina's Passion strives to connect different cultures from Eastern and Western Europe as well as Catholicism and the Orthodox rite. This unique piece, which contains an extensive vocal range, uses soloists, choirs, and instruments from the percussion family and organs. Although the work contains many modern elements, is clearly refers to Johann Sebastian Bach's work. Gubaidulina is a Russian of Tartar origin. She was born in 1931 and is currently considered one of the most interesting contemporary composers. When speaking about her works, she frequently refers to the past. She is fascinated by many historical moments, including: the musical renaissance, the great era of Wagner, and the achievements of the new Viennese school. The works of Bach, however, serve as her main inspiration. In addition, Gubaidulina is very inspired by multiculturalism. When interviewed, she frequently states:

I have a hunch that my personality has been formed by four different cultures. I inherited the Tatar culture from my father's family, and thanks to my mother I came to know Slavic culture. Teachers and the director of the music school, who was Jewish, played an important role in my life. I had such strong affinity for him because he was like a second father to me. However, German culture and the works of Goethe, Hegel, Novalis, Bach, Weber, Haydn, Mozart, and Beethoven were my spiritual inspiration. I feel a diversity of cultures within myself. ${ }^{1}$

Sofia Gubaidulina is also fascinated by numerology, a mathematical approach to the elements of musical works, as well as Fibonacci sequences, which contain many symbolic religious meanings. The spiritual dimension of art is also extremely important to her. Gubaidulina's St. John Passion was part of the Passion 2000 project and serves as a compendium of the mysticism and theological icon of the Orthodox rite. On both the macro and micro levels she uses religious symbols because it was undoubtedly very difficult to translate the content of the Passion into the musical tradition of the Orthodox rite, particularly because musical instruments are not used during the Orthodox liturgy. In addition, in Orthodox religious practices do not have any theatrical musical forms. Gubaidulina shared the following thoughts

A scene fom the film Fire and the Rosen, Portrait of Sofia Gubaidulina, BBC. Translator's translation. 
on this topic: "From the very beginning I realized the fundamental difficulty of writing a Passion in Russian. Russian tradition in the Orthodox Church does not permit the use of instruments during the Mass or during other church celebrations. There is no exterior technical intermediary between man and God-there is only one's own voice and a candle in one's hand. The most important, however, is the fact that the Orthodox church does not even have a tradition of performing the Passion. According to a Russian way of thinking, the 'art of presentation' was always considered secondary in relation to the 'art of direct experience.' Church custom, therefore, rejects the art of theatrical performance." 2

Although Gubaidulina does not draw from instrumental sources in Orthodox music (since the Orthodox liturgy does not use instruments), she still wrote her work for a huge orchestra, two choirs (one with 24 and another with 80 singers), five soloists-among whom the tenor and basso profondo served as the narrators. The composer also involved atypical instruments, including three Wagner tubas, a powerful range of percussion instruments with different sounds, organs, amplified pianos, and a synthesizer. All of the instruments play at the climax of the work. The prevalent parts of the work are used colorfully as they build surprising, mysterious, and mystical combinations of sound. The orchestral texture is rather rare, and the compositions focuses primarily on generating different shades of colorful connections, which creates the atmosphere of the entire work.

In her composition, Gubaidulina uses passages from the passion according to St. John as well as other biblical texts, but primarily the book of Revelation. She selected the texts in such a way that their context within the Orthodox religion is clear. Unlike previous Passion pieces, Gubaidulina's wrote a second part entitled St. John Easter. This two-part work, which returns to the composer's roots, is a kind of passage from darkness into light and, symbolically, from the betrayal of Christ and His death to the Resurrection. In Gubaidulina's work, she often uses the metaphor of the cross (e.g., in In croce, which is played on the cello). In addition, in the St. John Passion, there is a characteristic motif of the crossing (from one to the other) of the standing sounds with glissandos applied to them. Such an expression of the symbolism of the cross emphasizes the meaning of this most important symbol.

M. Anderson, Program festiwalu BBC Proms 2002, przeł. B. Bolesławska, cited in Książka programowa 46. Międzynarodowego Festiwalu Muzyki Współczesnej Warszawska Jesień, 2003, pg. 263. 
The Passion plays out in a spiral in which the passages from the Gospel and from Revelation are interwoven. The central part of this Passion piece is the crucifixion, which is presented in the subsequent sections of the work. The complete work is made up of eleven parts and constitutes a journey between Heaven and the Earth.

\begin{tabular}{|l|l|}
\hline HEAVEN & EARTH \\
\hline 1 - Das Wort (The Word) & 2- Fusswaschung (The Washing of the \\
6-Liturgie im Himmel & Feet) \\
(Liturgy in Heaven) & 3 - Das Gebot des Glaubens (The \\
9- Eine Frau, mit der & Commandment of Faith) \\
Sonne bekleidet (A Woman & 4 - Das Gebot des Liebe (The \\
Clothed with the Sun) & Commandment of Love) \\
11-Die sieben Schalen des & 5 - Hoffnung (Hope) \\
Zoms (The Seven Bowls of & 7-Verrat, Verleugnung, Geisselung, \\
Wrath) & Verurteilung (Betrayal, Denial, Flagellation, \\
& and Condemnation) \\
& 8-Gang nach Golgatha (The Way to \\
& Golgotha) \\
& 10-Grablegung - (Entombment) \\
\hline
\end{tabular}

In the first six parts of the work, Gubaidulina uses passages from St. John's Gospel. In the sixth section of her Passion, she uses passages from Revelation. Thanks to the bells that accompany the choral parts, this section sounds very Russian. After solemnly sounding the parts of the soprano, baritone, and accompanying choir, symbolic figures of the cross appears in the glissandos. In the second part of the work, which recalls the betrayal and condemnation of Christ, the work returns to the Gospel of St. John and supplements it with quotations from the Letter to the Hebrews and the Book of Isaiah.

The longest part of the passion is the Crucifixus. The figures of the cross are adapted in choral parties. In dense notes, the choirs dialogue with each other in both horizontal and vertical layers. Static harmonic sections mix with glissandos. The finale, which contains many expressive rhetorical figures, speaks about the plague that the seven angels brought upon the world. In the eighth part, the texts of the Gospel and the Apocalypse are interwoven in an interesting way, such that they coexist simultaneously. The bass soloist presents the Gospel passages, while a baritone sings the lyrics from Revelation. Two choirs accompany the soloists. On the way to Golgotha, the densest texture of intersecting voices occurs. The choral songs take on the role of the crowd (turba). The thick polyphony hearkens to the tradition of Bach. The polychorality of the two singing groups shows the corresponding 
relationship between worldliness and sanctity, tradition and modernity. The billowing sounds lead to the climax: "The final three parts successively convey: a short burst that expresses the power of the vision in A Woman Clothed with the Sun, an elevated moment during the Entombment (here Gubaidulina returns to the Gospel of St. John), as well as the terrible conclusion in The Seven Bowls of Wrath, where seven angels bring a plague down upon the earth. The only thing that remains is the Word, "and the Word was God."'3

Sofia Gubaidulina's short and characteristic St. John Passion is a Christian attempt to present the fate of man in an existential context. Although it is a deep philosophical reflection, the dominating feature of this music is its simplicity, which the composer specifies in an unusually simply way: "In a certain sense, my music is [...] dedramatized. I wanted all of the performers-musicians, soloists, and the orchestra - to be narrators... as if they were evangelists. This is a different concept than Bach's, where there are specific figures in the drama. In mine, this is not the case. The entire composition is epic. [...] It is a kind of story." 4

Gubaidulina's art is open to intercultural dialogue and the search for the meaning of humanity. Her musical expression is full of deep philosophical reflections. The delight, loftiness, spirituality, and gravity that dominate Gubaidulina's music situate her composition in a group of very unique and personal works that discuss the subject of religiosity and man's place in the world.

\section{Wolfgang Rihm - Deus Passus}

Wolfgang Rihm's Deus Passus, which was written completely in the tradition of European compositions, is the next work included in the Passion 2000 project. As a child, Rihm was very connected with the Church; he sang in church choirs and dreamed of becoming a priest. As a young man, he was deeply moved by a performance of Krzysztof Penderecki's Passion According to St. Luke. In 1970, Rihms went to Darmstadt, which was known as the mecca of twentieth-century contemporary music. Although Rihm was initially fascinated by the music of Karlheinz Stockhausen, he came to discover that his own musical language was closer to the works of the creators of the new

$3 \quad$ Ksią̇ka programowa 46. Międzynarodowego Festiwalu Muzyki Wspótczesnej Warszawska Jesień, 2003, pg. 263.

4 D. Cichy, M. Stochniol, Między Ewangelia a ciągiem Fibonacciego, "Ruch Muzyczny" 2008, 2, pg. 6. 
Theology of Beauty
Viennese school. He particularly liked the music of Webern and Berg. The creativity of the Viennese classics of the $20^{\text {th }}$ century, which were dominated by dodecaphonic thinking, inspired the works of Wolfgang Rihm who, although dodecaphonists disliked romantic aesthetics, remained cautious in this approach to music. He believed that music must always be very personal and contain emotional expression; consequently, he sought to express extreme emotional states in his music. He found such a subject in the Passion of Christ, which evokes many emotions. In Deus Passus, Rihm wanted to depict not only the suffering Christ, but to translate this suffering into the modern era by noting much of the violence, wars, and holocausts that have taken place during it. Rihm chose St. Luke's Gospel because it contains the fewest anti-Semitic references.

Rihm's entire work is divided into two scenes: The Way of the Cross and Jesus Between the Thieves. The composer refers only to three of the seven last words of Jesus on the cross. He ignores the most insignificant passages and presents what he believes to be the most important words. In this way, he removes all unnecessary information, descriptive adjectives, and third-person narration in the singular ("He said"), which is characteristic of the Gospels. Basically, he presents only the "skeleton" of historical event without oversimplifying it. This reduction liberates the text from rhetoric and literary features in order to present the most relevant information, thereby making the weight of the words that he chooses greater and more significant. According to Rihm, this arrangement of the text makes it not only an account that describes historical events, but also presents a universal message, the meaning of which is even closer to its contemporary recipients. These references to modern times and the danger, torment, and pain that it suffers make the problems that occurred more than two thousand years ago present today.

A noteworthy part of Deus Passus is the solo aria Und Jesus rief laut... [Jesus wept...], which is sung while a pulsating Bach harmony is played in the background. This part is exceptionally emotional and deeply lyrical, which can be heard in the instrumental echoes of Bach's structures that appear in the form of an oboe that corresponds to the soloists. The final part of Deus Passus presents a poem entitled Tenebrae, which was written by Paul Celan in 1959. This prayer is recited in Anglican and Protestant churches during Holy Week. In the poem, Celan-a Romanian-speaking German poet, refers to the atrocities of World War II. In a symbolic way he mentions the darkness of the light, the pain in it, and the immensity of human suffering. 
Against the wind we went there,

went there to bend

over hollow and ditch.

It cast your image into our eyes, Lord.

Our eyes and mouths stand open and empty, Lord.

We have drunk, Lord.

The blood and the image that was in the blood, Lord.

Pray, Lord.

We are near. ${ }^{5}$

Celan's poem is very poignant. The poet's parents met in a camp, and he himself spent his earliest years growing up in internment conditions. The poem Tenebrae, which was written after the end of World of Beauty War II, is a new type of poetry filled with grief and a prayer based on the author's present time. The lyrical subject of the work is the poet's inability to forgive God for not stopping the evil that the people experienced during the war. Throughout the remainder of his life, Celan, who had been steeped in the suffering of war, could not free himself from this experience and his atrocious memories of it, which led to his suicide in 1970. Wolfgang Rihm's choice of this poem was well thought out. Celan's deep grief associated with the atrocities of the war resulted in his tragic death, and Rihm interpreted this grief as a kind of contemporary suffering of the individual for the sins of others.

The end of Deus Passus reflects the tradition of Bach. It contains choral songs and harmonic chords that emerge against a choir of soloists who sing the lyrics "Nah sind wir, Herr [We are close]." This part, in which a limited number of instruments play, serves as a catharsis.

This work was written for five soloists, a chamber choir, a chamber orchestra with an oboe, English horn, harp, and organ. The trombones are the only brass instruments. The work is composed of twenty-seven fragments that chronologically tell of the events of the Passion. Not only is the length of the text reduced, so too is the instrumentation. Following in the footsteps of his master Berg, Rihm often uses instruments in a punctuated manner in order to create color rather than melody. Although Rihm hearkens to Berg, references to Bach's music can be found throughout Rihm's compositions. Overlooking the obvious connection of Rihm's use of same language as the Leipzig cantor, Rihm's work expresses his sense of the coherence of the traditions of

A passage from Paul Celan's poem Tenebrae, Sprachgitter, in Gesammelte Werke, vol. 1, S.H. (trans.), 1959, p. 163. 
both composers. Bach wrote his Passions primarily to bring the Gospel closer to the people and the people closer to God. Rihm creates parallels with Bach by presenting the suffering and sacrifices of victims of war and bringing the events of the Gospel into his own time. Seeking to convey a broad message, Rihm's work draw the listener's attention to search for a place for God in a modern world plagued by conflict.

Despite its bitter message, Deus Passus is filled with hope. In the work, the evil of the world ultimately collides with the values of faith, beauty with suffering and pain, and the sadness of many passages with heavenly arias. By building strong emotions through opposites, the composer makes the audience aware of the painful fact that great extremes create the fullness of humanity.

Helmuth Rilling's Passion 2000 project, which was intended to serve as a celebration of the anniversary of Bach's death, resulted in great works that are full of mysticism, dramaturgy, and references to modern times. The issue of the holocaust, postulates about a world without war, and social inequality all pervade contemporary Passion works. Supplementing the biblical accounts with the problems that affect the modern world results in a work that is significantly deeper and more universal than the traditional compositions.

Rilling's request played a significant role in reviving people's interest in Passion works. This project began a renaissance of this particular genre in the latest contemporary music, including contemporary Polish Passions. In 2008, Pawel Mykietyn debuted his Passion According to St. Mark, and in 2013 Dariusz Przybylski presented his work Passio et Mors Domini Nostri Iesu Christi Secundum Ioannem for 12 voices. These works are also experimental, which reveals how the evolution of the Passion genre of music that has occurred in recent decades has opened the genre and made space for sonoristic experiments and new contexts within the traditional framework of the Passion. Regardless of stylistic conventions and the means used, contemporary Passions have one overriding aim: to draw people's attention to the events of Christ's Passion that occurred more than two-thousand years ago.

The variety of compositional conventions of the Passions produced in response to Helmuth Rilling's project indicates that this genre is still open to innovation. The aesthetics, compositional techniques, and non-religious inspirations of contemporary Passion works demonstrate the new directions and developments have taken place within this genre. Modernity within the context of tradition as seen through the prism of various cultures creates a bridge between the variety of contemporaneity and the unchanging beauty of Bach's masterpieces. 
The Passions of the $20^{\text {th }}$ and $21^{\text {st }}$ centuries are not always characterized by suffering and humility only; instead, they sometimes boldly convey very new content and present resistance to the evil that surrounds us. Often these works convey contemporary history, and they create broad social contexts and expand the universal biblical message to be as current as possible.

Each time those who listen to Passion works and their subject matter they are made aware of the fragility of human life not only in relation to the overriding dogmas of the faith, but also in relation to the social and political realities in which they live and observe all kids of atrocities. Such an encounter with contemporary Passion music certainly makes one ponder, enter into an interior reverie, and cease hurrying to dominate every area of life. Those who compose Passions distinctly invigorate historical events from over two thousand years ago. They Theology of Beauty also make the subjects of injustice, pain, and suffering-issues that also dominate many areas of the contemporary world and are cause for anxiety-relevant.

\section{PASJA PRZEŁOMU XX I XXI WIEKU - SOFIA GUBAJDULINA, WOLFGANG RIHM}

Helmut Rilling, znakomity dyrygent, badacz muzyki bachowskiej zaproponował cenionym kompozytorom różnych narodowości napisanie dzieł pasyjnych inspirowanych tekstami czterech Ewangelii. Projekt Pasja 2000, zrealizowany z okazji 250 rocznicy śmierci Bacha, przyczynił się do powstania czterech zupełnie odmiennych dzieł, które wyznaczyły gatunkowi pasyjnemu nowe perspektywy. W ramach tej cennej inicjatywy, będącej ukłonem w stronę lipskiego mistrza gatunku, powstały cztery pasje kompozytorów odmiennych stylistycznie, wywodzących się z różnych tradycji i kultur. Efektem tego muzycznego zamówienia są znaczące dziś z perspektywy rozwoju pasji dzieła Rosjanki: Sofii Gubajduliny, Niemca: Wolfganga Rihma, Chińczyka: Tan Duna i Argentyńczyka: Osvaldo Goliova. Artykuł w perspektywie historycznej przybliża dwie europejskie pasje tego projektu: Johannes-Passion Sofii Gubajduliny i Deus Passus Wolfganga Rihma. Ich spojrzenie na gatunek pasji w omawianych kompozycjach poszerza tradycyjne ramy tego gatunku. Poszukiwanie punktów stycznych religii, nadawanie pasyjnym zdarzeniom współczesnych kontekstów i łączenie muzycznych stylów różnych epok to krótki zarys podejmowanej tematyki. 
Słowa kluczowe: Pasja, Wolfgang Rihm, Sofia Gubajdulina, współczesna muzyka sakralna, Johannes-Passion, Deus Passus.

\section{Bibliography:}

1. Anderson M., Program festiwalu BBC Proms 2002, przeł. B. Bolesławska, cited in Ksiażka programowa 46. Międzynarodowego Festiwalu Muzyki Wspótczesnej Warszawska Jesień, 2003, pg. 263.

2. Cichy D., Stochniol M., Między Ewangelia a ciagiem Fibonacciego, "Ruch Muzyczny" 2008, 2, pg. 6. 